\title{
The effect of stakeholder on firm value and environmental performance as intervening variable
}

\author{
Djoko Suhardjanto $^{1}$, Sigit Santosa ${ }^{2}$, Tri Fitrianto Suratno ${ }^{3}$, Rini Fatmawati ${ }^{4}$ \\ Universitas Sebelas Maret, Surakarta ${ }^{1,2,3,4}$ \\ djoko.suhardjanto@yahoo.com ${ }^{1}$, sigitsantosa@staff.uns.ac.id ${ }^{2}$, $\underline{\text { tri.fitrianto.suratno@gmail.com }}^{3}$, \\ rinifatmawati1993@gmail.com ${ }^{4}$
}

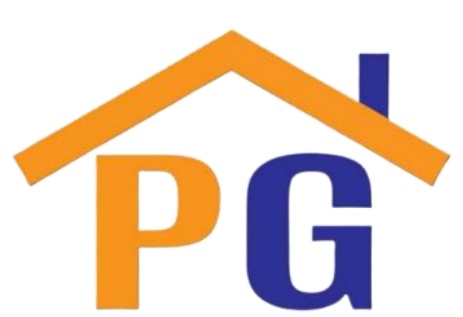

Riwayat Artikel

Diterima pada 28 Desember 2020

Revisi 1 pada 12 January 2021

Revisi 2 pada 14 January 2021

Disetujui pada 15 January 2021

\begin{abstract}
Purpose: This study aimed to understand the relationship between stakeholder and firm value with environmental performance as the intervening variable. The study was conducted on companies listed in Indonesia Stock Exchange and listed in the PROPER program during 2016 and 2017. The stakeholder variables in this study consist of managerial ownership (manager), consumer, and employee.
\end{abstract}

Research methodology: The samples were determined using purposive sampling with a total of 131 companies and using path analysis method as an expansion of regression analysis.

Result: The result is managerial ownership, consumer, and employee do not affect firm value directly. Managerial ownership has a positive and significant effect on firm value through environmental performance. The consumer has a significant and negative effect on the firm value through environmental performance and employee has a significant and negative effect on the firm value.

Limitation: The sample is limited for two years period and adjusted $\mathrm{R} 2$ is $21.5 \%$.

Contribution: This study can identify variables that affect firm value, especially: manager, consumer, employee and environmental performance.

Keywords: Firm value, Stakeholder, Environmental performance How to cite: Suhardjanto, D., Santosa, S., Suratno, T. F., \& Fatmawati, R. (2020). The effect of stakeholder on firm value and environmental performance as intervening variable. Jurnal Akuntansi, Keuangan, dan Manajemen, 2(1), 41-56.

\section{Introduction}

The activities with no ethics and morals base will have a negative effect on stakeholders and firm value. This explains that the decline in firm value might be caused by the decline in stakeholder's trust in the company. This is in line with the opinion from Sudiyatno (2010) that stock investment in the capital market is a high-risk investment and is very sensitive towards changes in the company, industry, and macroeconomic sectors. The changes have the potential to increase or reduce firm value. This study is based on the decline in firm value as a reaction from stakeholders. In the study conducted by Blacconiere and Pattern (1994), there is Union Carbide case in India, which shows that stakeholders react negatively toward the company's stock price. This occurs due to chemical leaks; therefore, its stock price kept declining for 45 days. According to Blacconiere and Pattern (1994), this indicates a decline in company performance.

PT. Lapindo Brantas has performed negligence in the oil and natural gas drilling. The negligence has resulted in mud volcano eruption that buried three subdistricts in Sidoarjo, East Java (www.thejakartapost.com. accessed on 8 January 2015). The accident leads to the decline in the stock 
price from PT. Energi Mega Persada as the major owner of PT. Lapindo Brantas, a subsidiary of Bakrie Group. The other case is BHP Billiton Ltd (BHP), whose stock price declined by $-2.45 \%$. The condition happened after a force majeure, in which BHP Billiton's Escondia in Cile, the biggest global mining company experience a decline in stock price due to two days strikes which stops its operation (www.bisnis.tempo.co accessed on 27 October 2017).

Firm value is a fundamental factor that investors must understand before they decide to invest their money in a certain company. Firm value is a certain condition of a company achieved as a representation of people trust in the company after going through a long production process since it is established. The increase in firm value is an achievement that meets what stakeholder wants. The increase in firm value will increase stakeholder's welfare. The company's main objective is to improve the owner's or stockholder's welfare through the improvement in firm value (Benson and Davidson, 2010). Firm value is important to be studied because it represents the growth and managerial performance of a company. Company growth is observed from the high valuation from external parties on the company's assets or stock market growth. Firm value is reflected in the stock price. If the stock price is high, the company has good value. Firm value can be increased by improving the company's performance.

Company with good environmental performance will give positive news to investors and future investors. Sudaryanto (2011) states that companies with high environmental performance positively respond to investors through their stock price fluctuation. The stock price is one of the alternatives to assess firm performance (Permanasari, 2010). Perez-Calderon et al. (2011) study in companies which belong to Dow Jones Responbility Index Europe shows environmental performance has effect on firm value. Haryono et all (2016) study conducted in Indonesia also shows that environmental performance affects firm value.

The difference in this study from previous studies is on its focus. Previous studies are more focused on disclosing the role of stakeholders on large companies in developed countries with a good stakeholder protection system (stakeholder-oriented countries) (Benson \& Davidson, 2010), while this study wants to reveal the role of stakeholders in companies located in a developing country, more specifically in Indonesia. The reasons for selecting Indonesia are: (a) Indonesia experiences great economic development, proved from Global Competitiveness Index which includes Indonesia in 37 most competitive countries globally in 2015-2016, fourth in Southeast Asia and ninth in Asia (www.worldbank.org, 2017), however, Indonesia is vulnerable to environmental damage and is weak on stakeholder protection (republika.co.id, 2017). (b) There is a limited number of studies on the field (Mishra Suar, 2010; Lin, Lee \& Lee, 2011). (c) Stakeholder in this study is proxied with the primary stakeholders that are limited to managers, consumers, and employees. (d) Environmental performance as intervening variable proxied with PROPER program or company performance rating program in environmental management performed by the Ministry of Environment. With PROPER, companies are rated from worst to best represented with black, red, blue, green, and golden (www.menlh.go.id/proper, 2017). PROPER will increase the credibility of company and trust of investor, because of the rank. The sample is used companies which are listed in Indonesia Stock Exchange and listed in PROPER Program for period 2016-2017 becasuse in these years the company with "black" category in PROPER is increasing significantly (PROPER Secretary, 2016).

The research questions answered in this study are: (1) Does managerial ownership affect firm value? (2) Does consumer affect firm value? (3) Does employee affect firm value? (4) Does managerial ownership affect firm value through environmental performance? (5) Does consumer affect firm value through environmental performance? (6) Does employee affect firm value through environmental performance? This study aims to answer the research questions formulated above, which are: (1) To test whether managerial ownership affects firm value. (2) To test whether consumer affects firm value. (3) To test whether employee affects firm value. (4) To test whether managerial ownership affects firm value through environmental performance. (5) To test whether consumer affects firm value through environmental performance. (6) To test whether employee affects firm value through environmental performance.

This study is expected to complete previous studies and provide benefits to various parties, such as: (1) For academics; the result of this study is expected to support stakeholder theory in explaining the decline in firm value that is mediated by environmental performance. (2) For management; this 
study provides an understanding of information openness in an effort to protect stakeholders. (3) For regulator; this study can act as a source of consideration in formulation policy and regulation on the protection for the stakeholder.

\section{Literature review and hypothesis development}

\subsection{Stakeholder theory}

Stakeholders are a group or individual who is capable of influencing a company or get affected by a company in their efforts to achieve the objectives (Parmar et al, 2010). A more comprehensive perspective states that stakeholders are individuals or group who have the claim, ownership, right, and interest on company's activities in the past, today, and future (Benn et al, 2016).

According to Benn et al (2016), based on their rights and interests, stakeholders are distinguished into two: primary stakeholders and secondary stakeholders. Stakeholder theory is defined as a continuous relationship and trust between stakeholders and a company in achieving company objective, to increase firm value, and to improve stakeholder welfare (Argandona, 2011). Company efforts to protect primary stakeholders such as the investor, creditor, consumer, supplier, employee, and manager by providing environmental information stated in PROPER as a form of corporate social responsibility, which in turn will improve stakeholders trust and firm value.

The considerations to use primary stakeholders are: (1) they have a direct effect on the continuity of the company (Venter et al, 2012). (2) they have an important role that encourages the company to always consider and protect stakeholder's interest and be responsible to social and environmental effect from its operation (LLC Law No. 40 of 2007).

\subsection{Manager}

Stakeholder theory has ethics (moral) and managerial focus. Ethics focussed stakeholder theory argues that all stakeholders have a right to be treated equally by the organisation, and managers have to manage the organisation to benefit all stakeholders (Harrison et al, 2015). Mainardes et al. (2011) use stakeholder theory to explain the objectives of a company in which one of them is to balance the conflict of interest among stakeholders, especially between managers and stockholders.

To reach high firm value, shareholders delegate their authority to the managers to manage their company. A manager who owns company stock or a manager who is also a stockholder will be motivated to improve his/her performance which is also expected by non-managerial stockholders (Boshkoska, 2015). The higher the proportion of managerial ownership in a company, the better is managers efforts to fulfil stockholder's interest because they will get benefits from their efforts as the stockholder. Stock ownership by managers will help managers in uniting their interest and stockholder's interest. Therefore, managers will be affected by the decision they take as well as bear the loss as the consequence of bad decision they take, directly (Jensen \& Mackling, 1976). Insider Ownership reflects the proportion of managerial stock ownership. It indicates that the manager who owns company stocks in large amount can act as a stockholder. Therefore, they will be more careful in every investment activity they take. According to Jensen \& Mackling (1976), the increase in stock ownership by the manager will help to harmonise manager's and stockholder's interest, therefore increasing firm value.

\subsection{Consumer}

According to Kamus Besar Bahasa Indonesia (kbbi.id, 2017), 'consumer' is the user of manufactured goods. A consumer is a part of primary stakeholders (Venter et al, 2012). A consumer is a key stakeholder who can help a company to build the reputation and competitive advantage.

The demand for product quality and safety can lead to the increase in sales or the decrease in consumer-related cost. High product quality and safety will also increase the company's profit (Mishra \& Suar, 2010). When consumers are not satisfied with a product or service; the sales will decline and consumer might file a lawsuit. It will directly affect the company's profit (Mishra \& Suar, 2010) and reduce the company's market price (Albari \& Safitri, 2018). Therefore, companies have to be careful on the factors such as standard advertising ethics, consumer's health and safety when using the product, company's quality program to provide better products with appropriate price, etc. (Mishra \& Suar, 2010).

Company's policy and practice to overcome those problems is corporate responsibility toward their consumers which can increase their firm value (Mishra \& Suar, 2010). Therefore, environmental 
performance is one of the company's efforts in protecting consumers (Nyilasy et al, 2013). The higher is the quality and safety of product offered by a company the higher is consumer repurchase intention because they are satisfied with the product offered.

\subsection{Employee}

According to KBBI/Kamus Besar Bahasa Indonesia (kbbi.id, 2017), 'employee' is people who work in an institution (office, company, and the kind) and get salary or wage. Together with the development of environmental awareness, employees start to pay attention to their company's environmental performance (Huang \& Kung, 2010). The employee has realised that passive environmental strategy might lead to poor environmental performance which may result in lawsuits and penalty, reputation damage, and finally injures employee's rights and interest (Huang \& Kung, 2010). Employee's rights and interest are highly related to the company's prospect; employees care about company's attitude towards its environmental strategy (Huang \& Kung, 2010).

The employee can push the management through their association to ensure that their aspirations are delivered to a managerial level in a company (Huang \& Kung, 2010). In this pressure, employees can actively implement environmental strategy and perform their social responsibility (Huang \& Kung, 2010). The larger the number of employees, the larger is their impact on the company's environmental policy. The employee can demand more comprehensive environmental information disclosure to avoid the loss of their rights and interests (Huang \& Kung, 2010), as well as to improve firm value since company implements the appropriate environmental strategy.

\subsection{Firm value}

According to Fama (1978), firm value is the level of company success in managing its resources, which is reflected in its stock price. According to Hong, Soonwook (2017), firm value is the total of debt market value and stock market value. Penman (2013) states that firm value as the return value of a company which is expected to be higher than its liability. From several definitions above, we can conclude that firm value is certain conditions achieved by a company as a depiction of people trust to the company.

The increase in firm value is an achievement and condition expected by management, investor, and stakeholder because it will improve stakeholder's welfare (Suhardjanto \& Nugraheni, 2012). Improving stakeholder's welfare is the duty and the responsibility of management besides maintaining a good relationship and trust from the stakeholder in managing the company (Suhardjanto \& Nugraheni, 2012).

Bestariningrum (2015) states that firm value can be measured through the development of stock price in the capital market. This due to firm value is basically the market value of stock added with the market value of bonds or long-term debts (Hermuningsih, 2013). Suhardjanto \& Nugraheni (2012) state that the increase in stock price reflects stakeholder's trust to the company since the increase in firm value will lead to the improvement of stakeholder's welfare which is expected by all related parties (Suhardjanto \& Nugraheni, 2012). According to Fu et al (2016), firm value can be proxied with Tobin's $\mathrm{Q}$ (modified Tobin's Q) and assessed by computing market value of all outstanding shares ratio added with total debts and divided with total assets.

Tobin's Q is the ratio of company's assets market value assessed through market value of total outstanding shares and debts (enterprise value) on the replacement cost of company's assets (Marsha \& Murtaqi, 2017). This shows that the company has a high incentive to generate new capital investment when the company's stock has a higher selling price than its investment cost (Fiakas, 2005). Tobin's Q score is a condition of investment opportunity owned by a company, the potential of company growth, and the assessment of company's performance from company's market price potential perspective (Tobin's, 1969).

\subsection{Environmental performance}

Environmental performance is the result of an environmental management system that can be measured and related to the control of environmental aspects such as ISO 14004 and ISO 14001 (Haslinda et al, 2010). According to Herawaty (2017), environmental performance is a company's

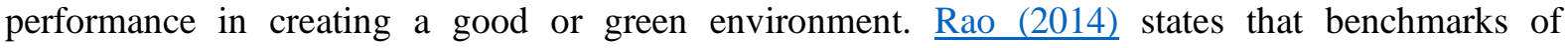


environmental performance used in the research are varied, it highly depends on the indicator adopted. There are four indicators of environmental performance: AMDAL, PROPER, ISO, and GRI.

Harahap et al (2018) reveals that company's environmental performance can be measured from company's achievement in joining the PROPER program which is one of the efforts performed by the Ministry of Environment (Kementerian Lingkungan Hidup-KLH) to encourage the implementation of company structure in managing the environment through information instruments. PROPER performance rating system consists of five colours which assigned consecutive points from five for golden and one for black (menlh.co.id, 2017).

\subsection{Corporate performance rating program (Program penilaian peringkat kinerja perusahaan- PROPER)}

PROPER is Corporate Performance Rating Program in environmental management. The objective of PROPER is to encourage the improvement of environmental management performance through the dissemination of information on a company's performance in managing environment (menlh.co.id, 2017). Performance improvement takes place through the incentive of and disincentive effect of reputation which may appear as a result of PROPER rating announcement to the public.

The incentive of public announcement is for companies that have food environmental performance with the blue, green, and gold label, while the disincentive is for companies with poor environmental management with the red and black label. Companies with red and black rank will get social sanction from the community, its stock price may go down, and its image may deteriorate because the company is regarded as disobedient to its environmental management. Stakeholders will appreciate companies with good rank and give pressure or encouragement to companies with poor rank to improve their environmental performance (menlh.go.id, 2017).

According to the Ministry of Environment (menlh.go.id, 2017) company will get golden rank when it has succeeded in implementing clean production and has performed 3R (Reuse, Recycle, and Recovery) as well as generating very satisfying result in environmental management. Companies get green rank when they have performed environmental management more than that required by the laws. Companies get blue rank when they have implemented environmental management according to the minimum requirements stated in the applicable laws. Companies get red rank they have not reached the minimum requirement regulated in the applicable law. Companies will get black rank when they pollute and damage the environment in their operation.

\subsection{Hypotheses development}

\section{The effect of managerial ownership on firm value}

Managerial ownership is a situation in which a manager owns company stock or in other words, the manager is also a stockholder in the company (Turmiwa \& Mamuaya, 2018). The manager will be motivated to improve his/her performance which is also expected by the stockholder. The higher the proportion of managerial ownership, the manager will be more inclined to improve their performance for stockholder's interest, which is him/herself.

Jansen and Mackling (1976) state that the increase in managerial ownership will harmonize manager and stockholder interests, therefore increase the firm value. This result is consistent with the study conducted by Rachman (2012) which prove that managerial ownership has a positive effect on firm value. Based on these arguments, we propose the following hypothesis:

\section{H1: Managerial ownership has a positive effect on firm value.}

\section{The effect of consumer on firm value.}

A consumer is a key stakeholder who can assist a company in building the reputation and competitive advantage. When the consumer is dissatisfied with product or service, sales will decline and the company might get lawsuits. It will directly affect the company's profit (Mirsha \& Suar, 2010) and reduce company market value (Nyilasy et al, 2013). The study that is in line with firm value determinant is consumer satisfaction Nguyen et al, 2018).

There are inconsistent results from previous studies. Srinivasan et al (2012) and Mirsha \& Suar (2010) state that consumers can increase firm value. Siregar et al (2018) state that consumer does not affect firm value. This study aims to retest the effect of consumer on firm value. If consumers are 
satisfied, they will repurchase the product, form loyalty, and increase firm value. Based on the result of previous study and argumentation above, we propose the following hypothesis:

\section{H2: Consumer has a positive effect on firm value.}

\section{The effect of employee on firm value.}

According to Nooraie (2012), the employee is directly involved and directly affect and participate in the company's important decision. In achieving the company's objectives, the company needs the active participation and support from their employees. The result from previous studies shows inconsistency. Srinivasan et al (2012) and Mirsha \& Suar (2010) state that employees can increase firm

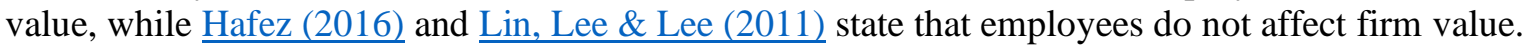

This study aims to retest the effect of employee on firm value. If there is good and continuous communication between employees and management, there will be trust from employees to help the company in achieving its objective. Based on the result of previous studies and argumentation above, we propose the following hypothesis:

\section{H3: Employee has a positive effect on firm value.}

\section{The effect of managerial ownership on firm value through environmental performance.}

A manager who has the company's stock or becoming company stockholder will be motivated to improve their performance which is also expected by the stockholders (Turmiwa \& Mamuaya, 2018).. Manager stock ownership can help to unite manager's and stockholder's interest; therefore, managers will be affected directly by the decision taken as well as bear the loss as the consequence of inappropriate decision they take (Jansen \& Mackling, 1976).

The previous study conducted by Esita \& Yanto (2016) shows that managerial ownership has a positive effect on environmental performance. Fortunella \& Hadiprajitno (2015) state that managerial ownership has no significant effect on environmental performance. A manager who is also stockholder might increase firm value because the increase in firm value will increase stockholder's wealth. One of the factors to increase of firm value is by increasing concern on the environment. The improvement in environmental performance is a form of company responsibility to the stakeholders. The better is the environmental performance, the better is the company's image in people's perception. High managerial ownership will encourage management to improve the company's environmental performance in order to build an image in people's eyes and therefore increase firm value. Based on the previous studies and arguments above, we propose the following hypothesis:

\section{H4: Managerial ownership has a positive effect on firm value through environmental performance.}

\section{The effect of consumer on firm value through environmental performance.}

A consumer is a key stakeholder who can assist the company in building the reputation and competitive advantage. The measurement that goes in line with non-financial information disclosure as the determinant of firm value is consumer satisfaction (Michelon, 2011; Mirsha \& Suar 2010). Consumer satisfaction demands the company to be more careful and improve their product quality, especially from the safety and environmentally friendly point of view. Therefore, the company improve its environmental performance, especially regarding their product. In order to make their consumer more satisfied with their products, the company can improve their product quality from its safety and environmental performance standpoint. Thus, environmental performance is the company's effort to protect their consumers (Horvathova, 2010).

The higher the quality and safety of a product, the higher will consumer intention to repurchase the product, because they are satisfied with the product. The result of the study conducted by Perez Calderon (2011), Ratri \& Dewi (2017), and Huang \& Kung (2010) state that consumer affects the environmental information disclosed by the company, in order to achieve a good rank in their environmental performance which will increase the firm value. Based on the arguments and the result from previous studies, we propose the following hypothesis:

H5: Consumer has a positive effect on firm value through environmental performance. 


\section{The effect of employee on firm value through environmental performance.}

Chen et al (2017) state that one of the important features of environmental information disclosure for employees is the ability to provide feedback to the management. Employees can push the company through labour union to ensure that their aspirations are delivered to managerial level in a company (Huang \& Kung, 2010). Under the pressure from their employees, the company should implement an environmental strategy and its social responsibility actively (Huang \& Kung, 2010). The larger the number of the employees, the stronger their influence on company environmental policies.

Employees may demand more disclosure of environmental information to avoid the loss of their rights and interests (Huang \& Kung, 2010). The result of a study conducted by Perez Calderon (2011), Ratri \& Dewi (2017), and Huang \& Kung (2010) state that employee is an inseparable part of company's environmental policy so that its environmental performance can be controlled. Thus, the firm value will be increased. Based on the description above, we proposed the following hypothesis:

H6: Employee has a positive effect on firm value through environmental performance.

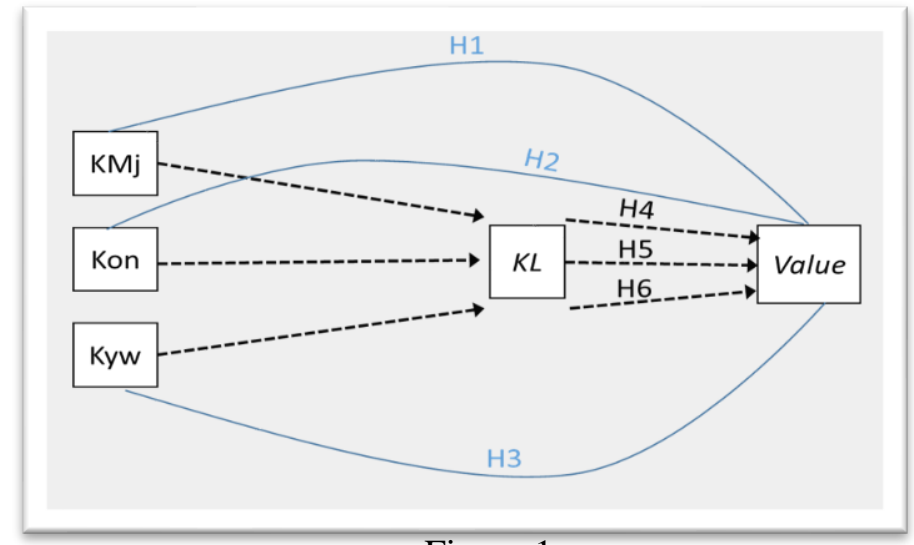

Figure 1

Conceptual Framework

The conceptual framework are shows in Figure 1 above. Where: KMj is "Managerial Ownership", Kon is "Consumer", Kyw is "Employee", KL is Environmental Performance, value is "Firm Value".

\section{Research methodology \\ Research design}

This study is conducted through hypothesis testing to test the effect of the independent variable of stakeholder which consists of manager, consumer, and employee, on firm value through company' environmental performance.

\section{Population, sample, and sampling technique}

The population in this study is all companies listed in Indonesia Stock Exchange and PROPER program during 2016 and 2017 and dominated with companies which are in mining, foresty, pharmacy, and consumer goods and its impact to the environment. The sampling is conducted through a nonprobability sampling method, in which the selection does not provide equal opportunity for all population members to be selected as a sample. Nonprobability sampling employed in the study is a purposive sampling; samples are selected based on the certain criteria developed to meet study objectives (Sekaran, 2011). The criteria are as follows: (1) Sample is company listed in Indonesia stock exchange and PROPER program and published an annual report in 2016 and 2017. (2) The company get PROPER rank in 2016 and 2017 through Ministry of Environment and Forestry Decree. The total samples analysed are company 131 annual reports.

\section{Data Tabulation}

\begin{tabular}{l|l|}
\hline $\begin{array}{l}\text { Total companies listed in Indonesia Stock Exchange and PROPER } \\
\text { program }\end{array}$ & 140 \\
\hline $\begin{array}{l}\text { Companies do not publish an annual report and are delisted in the } \\
\text { following year and data are not found in the Indonesia Stock }\end{array}$ & \\
Exchange official website (www.idx.co.id) & \\
\hline
\end{tabular}




\begin{tabular}{|c|c|}
\hline $\begin{array}{l}\text { Companies with no PROPER result due to review in } 2017 \text { for hotel } \\
\text { and hospital service. }\end{array}$ & (3) \\
\hline Total sampled companies & 131 \\
\hline
\end{tabular}

\section{Data and data collection method}

The data analysed are secondary data from company annual report in 2016 and 2017 and Ministry of Environment and Forestry Decree. The data are collected from Indonesia Stock Exchange website and Ministry of Environment and Forestry website.

\section{Variables and measurement \\ Firm value}

The dependent variable in this study is the firm value which is measured using Tobin's Q (modified Tobin's Q) formula. Firm value according to Penman (2013) is the level of company success in managing resources as a form of stakeholder's trust. The definition of Tobin's Q according to Chung and Pruitt (1994) is the ratio of company's market value as a substitute for the cost of assets. Previous studies that use Tobin's Q ratio as firm value are, among others: Suhardjanto \& Nugraheni (2012), Zulfikar (2006), and Justitia (2010). The formula of modified Tobin's Q used in this study is the formulation developed by Chung \& Pruitt (1994):

$$
Q=\frac{(\mathrm{MVS}+D e b t)}{T A}
$$

Notes:

$$
\begin{array}{ll}
\text { VALUE } & \multicolumn{1}{c}{=\text { Firm value. }} \\
\text { MVS } & =\text { Market Value of all outstanding shares. } \\
\text { Debt } & =\text { Debt. } \\
\text { TA } & =\text { Total Asset. }
\end{array}
$$

MVS is computed by multiplying stock price with total outstanding common stocks. Debt is computed from the short-term debts, added to tax payable, and book value of long-term debts. Total asset is computed from the book value of a company's total assets. Tobin's Q ratio higher than 1 means that company experiencing improvement, while less than 1 ratio shows that the company experiences decline.

\section{Managerial ownership}

Managerial ownership is a condition in which a manager owns company's stock or in other words, they also act as a stockholder (Tumiwa \& Mamuaya, 2018). According to Jansen \& Mackling (1976), the increase in managerial ownership will help to align manager's and stockholder's interest. Thus, it will increase firm value. Managerial ownership is measured using the proportion of stocks owned by managers (Rizani et al, 2018). Managerial ownership is measured from the percentage of stocks owned by the management.

$$
K M j=\frac{\text { stock owned by management }}{\text { Total stocks }}
$$

\section{Consumer}

A consumer is a key stakeholder who can assist a company in building the reputation and competitive advantage. When a consumer is dissatisfied with a product or service, sales will decline and company might get lawsuits. It will directly affect the company's profit (Mirsha \& Suar, 2010) and decrease the company's market value (Nyilasy, 2013). The measurement that goes in line with nonfinancial information disclosure as the determinant of firm value is consumer satisfaction (Muksin et al, 2018; Mirsha \& Suar 2010). According to Payne in Hoe et al (2018), product quality is a construct with complicated satisfaction value. Consumers buy a product to solve their problems and they will assess the product. The value consumers attached to a product is related to the benefit they gain from the product. The measurement of consumer satisfaction can be measured from the difference between revenue from the previous year with revenue in the current year. 


\section{Employee}

Employee is the individual who works in an institution, either an office, company, and so on and receive a salary or wage. Employee in this study is proxied with the total number of employees in the company. The use of this proxy refers to the study conducted by Huang \& Kung (2010) and Nandani (2017). The formula is as follows:

$$
\text { Employee }=\sum \text { company's performance }
$$

\section{Environmental performance}

Sorooshian (2016) states that the measurement of performance used in the studies are greatly varied, depend on the indicators, there are four indicators: AMDAL, PROPER, ISO, and dan GRI. Handoyo. (2018) reveals that company's environmental performance can be measured from company's achievement in the PROPER program conducted by the Ministry of Environment to encourage the implementation of company structure in managing environmental through information instrument.

PROPER Scoring

\begin{tabular}{clcc}
\hline No & Colour & Notes & Score \\
\hline 1 & Gold & Excellent & 5 \\
2 & Green & Very Good & 4 \\
3 & Blue & Good & 3 \\
4 & Red & Poor & 2 \\
5 & Black & Very Poor & 1 \\
\hline
\end{tabular}

\section{Data analysis method}

This study uses descriptive statistic analysis and hypothesis testing through multiple linear regression model and path analysis. Statistical analysis is performed on SPSS release 23 program.

\section{Descriptive analysis}

Descriptive statistic consists of mean, median, the standard of deviation, maximum and minimum score. This analysis aims to provide the description of the distribution and the behaviour of data.

\section{Hypothesis testing}

This study has two regression formulas. The first formula is used to test the effect of managerial ownership, consumer, and employee on environmental performance. The second formula is used to test the effect on managerial ownership, consumer, employee, and environmental performance on firm value. Both regression formulas are:

Notes:

$$
\begin{gathered}
\mathrm{KL}=\beta 1 K M j+\beta 2 K o n+\beta 3 K y w+\epsilon 1 \\
\mathrm{VALUE}=\beta 1 K M j+\beta 2 K o n+\beta 3 K y w+\beta 4 K L+\epsilon 1
\end{gathered}
$$

KL : Environmental Performance

VALUE : Firm value

KMj : : Managerial Ownership

Kon : Consumer

Kyw : Employee

$\beta \quad:$ standardised regression coefficient

$\epsilon \quad$ : Error 


\section{Results and discussions \\ Descriptive analysis}

Descriptive statistic testing is data processing used to see the distribution of data collected from 131 companies. The results of this testing are the minimum value, maximum value, mean score, and standard deviation. The results of descriptive statistics testing are as follows:

Table 1

The Results of Descriptive Statistic Testing

\begin{tabular}{|l|r|r|r|r|r|}
\hline & $\mathrm{N}$ & Minimum & Maximum & \multicolumn{1}{c|}{ Mean } & Std. Deviation \\
\hline Managerial Ownership & 131 & 0.00 & .32 & .0232 & .06257 \\
Consumer & 131 & -.50 & .53 & .0556 & .15502 \\
Employee & 131 & 144.00 & 83310.00 & 8898.3664 & 14288.55620 \\
Environmental & 131 & 2.00 & 5.00 & 3.0763 & .44060 \\
Performance & 131 & .14 & 11.31 & 1.1593 & 1.40836 \\
Firm value & 131 & & & & \\
Valid N (listwise) & & & & \\
\hline
\end{tabular}

Source: processed secondary data (2018)

In table 1, the results of descriptive statistic testing show that there are 131 companies sampled. On average, the companies have $2.32 \%$ managerial ownership. The highest level of managerial ownership is $32 \%$ in Bukaka Teknik Utama Tbk, and the lowest is $0 \%$ which is the case in 71 companies.

On average, customer satisfaction shows an increase of $5.56 \%$. The increase in consumer satisfaction is 53\% in Bukaka Teknik Utama Tbk in 2017. The lowest change in consumer satisfaction is $-50 \%$ in Citra Tubindo Tbk.

The largest number of employees is 83,310 and owned by Indofood Sukses Makmur Tbk. The lowest number of employees is 144 in Taisho Pharmaceutical Indonesia Tbk.

The best PROPER rank is 5, Tambang Batubara Bukit Asam Tbk in 2016 and the worst rank is 2 in 2016 with four companies, Akasha Wira International (ADES), Bukaka Teknik Utama, Panasia Indo Resource, and Martina Berto, while in 2017 there are three companies, Kimia Farma, PP London Sumatera Indonesia, and Semen Baturaja.

In average the companies have the firm value of 1.4084. The highest firm value is 11.31 in Multi Bintang Indonesia in 2016 and the lowest firm value is 0.14 in HM Sampoerna in 2016.

Model Analysis for Formula 1

\begin{tabular}{|c|c|c|c|c|c|}
\hline \multirow[t]{2}{*}{ Variable } & \multicolumn{2}{|c|}{$\begin{array}{l}\text { Unstandardized } \\
\text { Coefficients }\end{array}$} & \multirow{2}{*}{$\begin{array}{c}\begin{array}{c}\text { Standardize } \\
\text { d } \\
\text { Coefficient }\end{array} \\
\text { Beta }\end{array}$} & \multirow[t]{2}{*}{$\mathbf{T}$} & \multirow[t]{2}{*}{ Sig. } \\
\hline & B & Std. Error & & & \\
\hline (Constant) & 3.213 & 0.37 & & 8.693 & 0.000 \\
\hline Managerial Ownership & 0.826 & 0.253 & 0.223 & 3.272 & 0.001 \\
\hline Consumer & -0.314 & 0.104 & -0.080 & -3.019 & 0.003 \\
\hline Employee & -1.009 & 0.097 & -0.730 & -10.373 & 0.000 \\
\hline Adjusted R Square & \multicolumn{5}{|c|}{0.927} \\
\hline $\mathrm{F}$ & \multicolumn{5}{|c|}{551.182} \\
\hline $\mathrm{F}(\operatorname{sig})$ & \multicolumn{5}{|c|}{0.000} \\
\hline
\end{tabular}

Notes: $* \mathrm{p}<0.05$.

Dependent Variable: Environmental Performance.

Source: processed secondary data (2018). 
Model Analysis for Formula 2

\begin{tabular}{|c|c|c|c|c|c|}
\hline \multirow[t]{2}{*}{ Variable } & \multicolumn{2}{|c|}{$\begin{array}{c}\text { Unstandardized } \\
\text { Coefficients }\end{array}$} & \multirow{2}{*}{$\begin{array}{c}\text { Standardized } \\
\text { Coefficient }\end{array}$} & \multirow[t]{2}{*}{$\mathbf{t}$} & \multirow[t]{2}{*}{ Sig. } \\
\hline & B & Std. Error & & & \\
\hline (Constant) & 0.569 & 0.200 & & 2.843 & 0.005 \\
\hline Managerial Ownership & -0.086 & 0.252 & -0.030 & -0.342 & 0.733 \\
\hline Consumer & 0.296 & 0.189 & 0.141 & 1.564 & 0.120 \\
\hline Employee & -0.009 & 0.046 & -0.015 & -0.187 & 0.852 \\
\hline $\begin{array}{l}\text { Environmental } \\
\text { Performance }\end{array}$ & 0.272 & 0.044 & 0.512 & 6.249 & 0.000 \\
\hline Adjusted R Square & & & 0.215 & & \\
\hline $\mathrm{F}$ & & & 9.901 & & \\
\hline$F(\operatorname{sig})$ & & & 0.000 & & \\
\hline
\end{tabular}

Notes: $* \mathrm{p}<0.05$.

Dependent Variable: Firm value.

Source: processed secondary data (2018).

The coefficient of determination is detected from the adjusted R-Square. From the first regression, the adjusted R-square score is 0.927 . This shows that $92.7 \%$ of the variances in environmental performance is explained by independent variable managerial ownership, consumer, and employee, the rest $7.3 \%$ is explained by other variables outside the model. In the second model, the adjusted R-Square score is 0.215 . This shows that $21.5 \%$ of the variances in firm value is explained by managerial ownership, consumer, employee, and environmental performance, the rest $78.5 \%$ is explained by other variables outside the model.

$\mathrm{F}$ (sig) score in both formulas are $0.000<0.05$. Therefore, we can conclude that the multiple regression model is excellent. Simultaneously, the independent variables have the ability to affect the dependent variable.

\section{The result of path analysis}

Path Analysis is a technique to analyse the causal relationship in multiple linear regression model. When the dependent variable is not only affected directly by the independent variables but also indirectly. From both linear regression analysis performed, we conduct path analysis for indirect effect, direct effect, and total effect with the following results:

The Results of Path Analysis

\begin{tabular}{clccc}
\hline No & $\begin{array}{c}\text { Direction of } \\
\text { Relationship }\end{array}$ & $\begin{array}{c}\text { Direct } \\
\text { Effect }\end{array}$ & Indirect Effect & $\begin{array}{c}\text { Total } \\
\text { Effect }\end{array}$ \\
\hline 1 & $\mathrm{KMj} \rightarrow \mathrm{KL}$ & 0.223 & -- & -- \\
2 & $\mathrm{Kon} \rightarrow \mathrm{KL}$ & -0.080 & -- & -- \\
3 & $\mathrm{Kyw} \rightarrow \mathrm{KL}$ & -0.730 & -- & -- \\
4 & $\mathrm{KMj} \rightarrow \mathrm{FV}$ & -0.030 & -- & -- \\
5 & $\mathrm{Kon} \rightarrow \mathrm{FV}$ & 0.141 & -- & -- \\
6 & $\mathrm{Kyw} \rightarrow \mathrm{FV}$ & -0.015 & -- & -- \\
7 & $\mathrm{KL} \rightarrow \mathrm{FV}$ & 0.512 & -- & -- \\
8 & $\mathrm{KMj} \rightarrow \mathrm{KL} \rightarrow \mathrm{FV}$ & -- & 0.114 & 0.084 \\
9 & $\mathrm{Kon} \rightarrow \mathrm{KL} \rightarrow \mathrm{FV}$ & -- & -0.041 & 0.100 \\
10 & $\mathrm{Kyw} \rightarrow \mathrm{KL} \rightarrow \mathrm{FV}$ & -- & -0.374 & 0.138 \\
\hline
\end{tabular}

Source: processed secondary data (2018)

Notes:

KMj : Managerial Ownership 
Kon : Consumer

Kyw : Employee

KL : Environmental Performance

FV : Firm value

\section{Hypothesis testing}

The result of hypothesis testing for $\mathrm{H} 1$ is, managerial ownership has no effect on firm value because the level of significance is $0.733>0.05$. H1 which states that managerial ownership affects firm value is not supported. Managerial ownership has no effect on firm value because from all companies sampled, the managerial ownership is lower than $32 \%$. Therefore, it has no effect on the increase or decrease of firm value.

The result of testing of $\mathrm{H} 2$ shows that consumer does not affect firm value because the level of significance is $0.120>0.005$. This means the second hypothesis which states that consumer has a positive effect on firm value is not supported. This shows that revenue change as a proxy of consumer satisfaction has no effect on the increase or decrease of firm value. The increase in sales from the previous year only affect current profitability. This result is in line with the argument from Vracheva and Mason (2015) that consumer has no effect on firm value.

The result of testing on $\mathrm{H} 3$ shows that there is no effect of employee on firm value because the level of significance is $0.852>0.005$. This makes the hypothesis 3 which states that employee has a positive effect on firm value is not supported. This is in line with the argument from Wahba (2013) that if a company has fulfilled the explicit contract, the employee cannot affect the policies and business sustainability. The explicit contract in legal term can be translated as the relationship between company and stakeholders.

The result of testing for $\mathrm{H} 4$ is managerial ownership through environmental performance has a significant effect because of $p$-value $<0.05$. The regression coefficient is 0.114 which shows a positive effect. Therefore, $\mathrm{H} 4$ which states that managerial ownership has a positive effect on firm value through environmental performance is supported. If directly, managerial ownership has no effect on firm value, with environmental performance as a mediating variable, managerial ownership has a positive effect on firm value. High managerial ownership will encourage management to improve environmental disclosure in order to get an acceptable image from the community and increase firm value.

The result of testing on $\mathrm{H} 5$ shows that consumer through environmental performance has a significant effect because of $p$-value $<0.05$. The regression coefficient is -0.041 and shows a negative effect. H5 which states that consumer has a positive effect on firm value through environmental performance is not supported. Consumer does not directly affect firm value but is mediated by environmental performance, so that it has a significant effect with a negative value. The increase in sales cannot directly be attributed to the increase in firm value.

The result of testing on hypothesis 6 shows that employee through environmental performance has a significant effect because of p-value $<0.05$. The coefficient of regression is -0.374 which show a negative effect. Therefore, $\mathrm{H} 6$ which states that employee has a positive effect on firm value through environmental performance is not supported. Employee does not affect firm value directly, however, when mediated by environmental performance, it has a negative and significant effect on firm value.

\begin{tabular}{ccccc}
\hline No & Hypothesis & Variable & $\begin{array}{c}\text { Coefficient } \\
(\mathbf{s i g})\end{array}$ & Conclusion \\
\hline 1 & $\mathrm{H} 1$ & $\mathrm{KMj} \rightarrow \mathrm{FV}$ & $-0.03(0.733)$ & No effect \\
2 & $\mathrm{H} 2$ & $\mathrm{Kon} \rightarrow \mathrm{FV}$ & $0.141(0.12)$ & No effect \\
3 & $\mathrm{H} 3$ & $\mathrm{Kyw} \rightarrow \mathrm{FV}$ & $-0.015(0.852)$ & No effect \\
4 & $\mathrm{H} 4$ & $\mathrm{KMj} \rightarrow \mathrm{KL} \rightarrow \mathrm{FV}$ & 0.114 & Significant positive \\
5 & $\mathrm{H} 5$ & $\mathrm{Kon} \rightarrow \mathrm{KL} \rightarrow \mathrm{FV}$ & -0.041 & Significant negative \\
6 & $\mathrm{H} 6$ & $\mathrm{Kyw} \rightarrow \mathrm{KL} \rightarrow \mathrm{FV}$ & -0.374 & Significant negative \\
\hline
\end{tabular}

Source: processed secondary data (2018) 
Notes:

$\mathrm{KMj}$ : Managerial Ownership

Kon : Consumer

Kyw : Employee

KL : Environmental Performance

FV : Firm value

\section{Conclusion}

Based on the result of regression testing, we conclude that managerial ownership, consumer, and employee do not affect firm value directly. This is due to firm value is affected by other factors or variables. This result contradicts the result from Agustia et al (2018), Mirsha \& Suar (2010), and Rachman (2012).

Managerial ownership, consumer, and employee simultaneously have a significant direct effect on firm value of $92.7 \%$. This result is consistent with the study conducted by Dewata \& Banaluddin (2012), Huang \& Kung (2010), and Ruan et al (2011).

Environmental performance has a significant and positive effect on firm value of $51.1 \%$. This can be explained by the fact that companies usually improve their environmental performance so that investor responds positively and then increase firm value through the increase in stock price. This result is consistent with the study conducted by Falichin (2011).

Managerial ownership, consumer, and employee have an indirect significant effect on firm value through the environmental performance of 0.322 or $32.2 \%$. The stakeholders in this study; manager, consumer, and employee have the interest to increase firm value because they want high return/feedback from the company and gain benefit from the company. One of the ways to build company reputation is by improving environmental performance because environmental performance has a positive effect on firm value. This is in line with the study conducted by Perez-Calderon (2011). This study has limtitations such as: adjusted R2 is $21.5 \%$, period of sample, and research variables. Future studies have to use larger samples with longer observation period and not limited to two years. Based on the result of the regression analysis, both Adjusted R2 is still low with $21.5 \%$. Therefore, future studies may add other variables that match with stakeholder theory, for example, investor, creditor, government, media, and the society.

\section{References}

Albari \& Safitri. (2018). The influence of product price on consumers' purchasing decisions. Review of Integrative Business and Economics Research, 7(2).

Agustia et al. (2018). Managerial ownership, corporate social responsibility disclosure and corporate performance. Management of Sustainable Development Sibiu, Romania, 1(2), December 201810.2478/msd-2019-0011.

Argandona, Antonio. (2011). Stakeholder theory and value creation. IESE Business School University of Navarra.

Benn et al. (2016). Defining and identifying stakeholders: Views from management and stakeholders. S.Afr.J. Bus.Manage, 47(2).

Benson, Bradley W. \& Davidson, W. (2010). The relation between stakeholder management, firm value and CEO compensation: a test of enlightened value maximization. Financial Management.

Bestariningrum, Nenggar. (2015). Analyzing the effect of capital structure and firm size on firm value (Case Study: Company That listed In Lq-45 Index Period 2010-2014). Jurnal Berkala Ilmiah Efisiensi, 15(4).

Blacconiere, W. \& Patten, D. (1994). Environmental disclosures, regulatory costs, and changes in firm value. Journal of Accounting and Economics, 18 (3), 357-377.

Boshkoska, Meri. (2015). The agency problem: measures for its over. International Journal of Business and Management; 10(1).

Chen, Y.-C.; Hung, M.; Wang, Y. (2017). The effect of mandatory CSR disclosure on firm profitability and social externalities: Evidence from china. J. Account. Econ, 65, 169-190.

Chung, K. H., \& Pruitt, S. W. (1994). A simple approximation of Tobin's q. Financial management, 70-74. 
Dewata \& Banaluddin. (2012). The effect of ownership structure on firm value in Indonesia. EBES 2012 Istanbul Conference.

Esita \& Yanto. (2016). The effect of good corporate governance mechanism (managerial ownership) on corporate value with environmental performace as an intervening variable. Accounting Analysis Journal AAJ, 5(3). http://journal.unnes.ac.id/sju/index.php/aaj

Falichin, M.Z. (2011). Pengaruh Corporate Social Responsibility Disclosure terhadap reaksi investor dengan Environmental Performance Rating dan Corporate Governance sebagai Variabel Moderasi. Undergraduate Thesis. Universitas Diponegoro.

Fama, E.F. (1978). The effect of a firm's investment and financing decision on the welfare of its security holders. American Economic Review, 68, 272-280.

Fiakas, D. (2005). Tobin's q: valuing small capitalization companies, Crystal Equity Research, April.

Fortunella \& Hadiprajitno. (2015). The effects of corporate governance structure and firm characteristic towards environmental disclosure. Diponegoro Journal of Accounting, 4(2), 1-11.

$\mathrm{Fu}$ et al. (2016). Tobin's q ratio and firm performance. International Research Journal of Applied Finance, 7(4).

Hafez M, Hasan (2016). Corporate Social Responsibility and Firm Value: an empirical study of an emerging economy. Journal of Governance and Regulation, 5(4).

Harahap et al. (2018) The impact of environmental performance and profitability on firm value. Indonesian.

Handoyo, Sofik. (2018). The development of Indonesia environmental performance and environmental compliance. Journal of Accounting Auditing and Business, 1(1), 8. Doi: 10.24198/jab.vlil.15656.

Harrison et al (2015). Stakeholder theory as an ethical approach to effective management: applying the theory to multiple contexts. Rev. bus. manag., São Paulo, 17(55), 858-869. DOI:10.7819/rbgn.v17i55.2647.

Haryono et al. (2016). Sustainability performance: it's impact on risk and value of the firm. Corporate Ownership \& Control, 14(1), Continued - 1 .

Haslinda, A., Fuong, C. C. (2010). The implementation of ISO 14001, environmental management system in manufacturing firms in Malaysia. Asian Social Sciences, 6(3), 100-107.

Herawaty. (2017). The effect of environmental performance and accounting characteristics to earnings informativeness. The 4th International Seminar on Sustainable Urban Development IOP Publishing. consume

Hermuningsih, Sri. (2013). Profitability, growth opportunity, capital structure and the firm value. University of Sarjanawiyata Tamansiswa Yogyakarta.

Hoe et al. (2018). The effect of product quality on customer satisfaction and loyalty: evidence from malaysian engineering industry. International Journal of Industrial Marketing, 3(1).

Hong, Soonwook. (2017) The effect of debt choice on firm value. The Journal of Applied Business Research, 33, 1.

Horvathova, E. (2010). Does environmental performance affect financial performance? A Metaanalysis. Ecol. Econ, 70, 52-59.

Huang, C. \& Kung, F. (2010). Drivers of environmental disclosure and stakeholder expectation: evidence from Taiwan. Journal of Business Ethics, 96, 435-451.

Jensen, M.C. \& Meckling, W. H. (1976). Theory of the firm: managerial behavior, agency costs, and ownership structure. Journal of Financial Economics, 3, 305-360.

Justitia, A.H. (2010). Perbedaaan rasio keuangan dan nilai perusahaan sebelum dan sesudah memperoleh sertifikat Corporate Governance Perception Index (CGPI). Undergraduate Thesis. Fakultas Ekonomi Universitas Sebelas Maret.

Law Number 40 of 2007 regarding Limited Liability Company.

Lin, M., Lee, D., \& Lee, L. (2011). Using Tobin's Q ratio to testing the stakeholder theory applied to the corporate social performance. African Journal of Business Management, 5, 12951-12957.

Mainardes et al. (2011). Stakeholder theory: issues to resolve. Management Decision, 49(2), 226-252.

Marsha \& Murtaqi. (2017). The effect of financial ratios on firm value in the food and beverage sector of the IDX. Journal of Business and Management, 6, (2), 214-226.

Michelon, G. (2011). Sustainability disclosure and reputation: A comparative study. Corp. Reput. Rev. $14,79-96$. 
Mishra, Supriti \& Suar, D. (2010). Does Corporate Social Responsibility influence firm performance of Indian Companies?. Journal of Business Ethics, 95, 571-601.

Muksin et al, (2018). Determinants of customer's equity: an empirical studies on BPRS Customers in Ex Banyumas Residency Central Java. International Review of Management and Marketing, $8(2), 81-89$.

Nandani, S.I. (2017). Pengaruh ukuran dewan direksi, ukuran dewan komisaris, ukuran perusahaan, dan jumlah karyawan terhadap kinerja keuangan perusahaan (Studi kasus pada Perusahaan BUMN yang terdaftar di BEI pada tahun 2010-2014). Undergraduate thesis, Universitas Muhammadiyah Semarang.

Nyilasy et al. (2013). Perceived greenwashing: the interactive effects of green advertising and corporate environmental performance on consumer reactions. J Bus Ethics. DOI 10.1007/s10551-0131944-3.

Nguyen et al. (2018). Determinants of Customer Satisfaction and Loyalty in Vietnamese Life-Insurance Setting. $\quad$ Sustainability, $10, \quad 1151 ; \quad$ doi:10.3390/su10041151 www.mdpi.com/journal/sustainability.

Nooraie, M. (2012), Factors influencing strategic decision-making processes. International Journal of Academic Research in Business and Social Sciences, 2(7), 405-429.

Parmar et al. (2010). Stakeholder theory: the state of the art. Cambridge University Press.

Penman, H.S. (2013). Financial statement analysis and security valuation (5th es.). NY: McGraw-Hill Companies, Inc.

Permanasari, W.E. (2010). Pegaruh kepemilikkan manajemen, kepemilikkan institusional dan CSR terhadap Nilai Perusahaan. Undergraduate Thesis. Universitas Diponegoro.

Perez-Calderon et al. (2011). Eco-efficiency: effects on economic and financial performance. evidences From Dow Jones Sustainability Europe Index. Environmental Engineering and Management Journal, 10(12), 1801-1808.

PROPER. (2015). Program penilaian peringkat kinerja perusahaan dalam pengelolaan lingkungan hidup. www.menlh.go.id/proper accessed on 26 October 2017.

Rachman, A.A. (2012). Pengaruh Corporate Social Responsibility, kepemilikan manajerial, dan kepemilikan institusional terhadap nilai perusahaan pada perusahaan manufaktur yang terdaftar di BEI tahun 2008-2010. Jurnal Sekolah Tinggi Ilmu Ekonomi Surabaya.

Ratri \& Dewi. (2017). The effect of financial performance and environmental performance on firm value with Islamic Social Reporting (ISR) disclosure as intervening variable in companies listed at Jakarta Islamic Index (JII). DOI: 10.1051/shsconf/20173412003.

Rao H, Purba. (2014). Measuring environmental performance across a green supply chain: a managerial overview of environmental indicators. Vikalpa, 1.

Rizani et al. (2018). Managerial ownership is measured using the proportion of stocks owned by managers. 2nd Padang International Conference on Education, Economics, Business and Accounting (PICEEBA-2 2018).

Ruan et al. (2011). Managerial ownership, capital structure and firm value: evidence managerial ownership, capital structure and firm value: evidence from China's Civilian-run Firms from China's Civilian-run Firms. Australasian Accounting, Business and Finance Journal Australasian Accounting, Business and Finance Journal, 5(3).

Sekaran, Uma. (2011). Research methods for business (Metode penelitian untuk. bisnis). Jakarta: Salemba Empat. Suandy, Erly. 2011.

Sekretariat PROPER Ditjen pengendalian pencemaran \& kerusakan lingkungan Kementerian Lingkungan Hidup \& Kehutanan, (2016).

Siregar et al. (2018). Firm value predictor and the role of Corporate Social Responsibility. Jurnal Keuangan dan Perbankan, 22(3), 475-485.

Sorooshian et al. (2016). Review on performance measurement systems. Mediterranean Journal of Social Sciences MCSER Publishing, Rome-Italy, 7(1). Doi:10.5901/mjss.2016.v7n1p123.

Srinivasan et al. (2012). Branding and firm value. DOI: 10.4337/9781849802727.00016.

Sudaryanto. (2011). Pengaruh kinerja lingkungan terhadap kinerja finansial perusahaan dengan Coorporate Social Responsibility (CSR) sebagai Variabel Intervening. Undergraduate Thesis. Universitas Diponegoro. 
Sudiyatno, B. \& Puspitasari, E. (2010). Pengaruh kebijakan perusahaan terhadap nilai perusahaan dengan kinerja perusahaan sebagai variabel intervening. Dinamika Keuangan dan Perbankan, 2(1), 1-22.

Suhardjanto, D. \& Nugraheni, S. (2012). Pengaruh Corporate Social Responsibility (CSR) Disclosure terhadap nilai perusahaan. Jurnal Akuntansi, 16, 162-175.

Tobin's, J. (1969). A general equilibrium approach to monetary theory. Journal of Money, Credit and Banking (February), 12-29.

Tumiwa \& Mamuaya. (2018). The influence of managerial ownership and institutional ownership on agency costs (Studies on manufacturing companies in the basic industrial and chemical sectors listed on the Indonesia Stock Exchange). International Journal of Applied Business \& International Management, 3(1).

Venter et al. (2012). The impact of selected stakeholders on family business continuity and family harmony. Southern African Business Review, 16(2).

Vracheva, V. \& Mason, R. (2015). Creating firm value through stakeholder management and regulation. Journal of Managerial Issues, 27, 1-4.

Wahba, Hayam. (2013). Capital structure, managerial ownership and firm performance: evidence from Egypt. Springer, DOI 10.1007/s10997-013-9271-8.

Zulfikar. (2006). Analisis Good Corporate Governance di sektor manufaktur: pengaruh penerapan Good Corporate Governance, Return on Asset, dan ukuran perusahaan perusahaan terhadap nilai Perusahaan. Benefit, 10(2), 130-141.

www.bisnis.tempo.co

www.kbbi.id accessed on 26 October 2017.

www.republika.co.id accessed on 26 October 2017.

www.thejakartapost.com. accessed on 8 January 2015

www.worldbank.org accessed on 26 October 2017. 